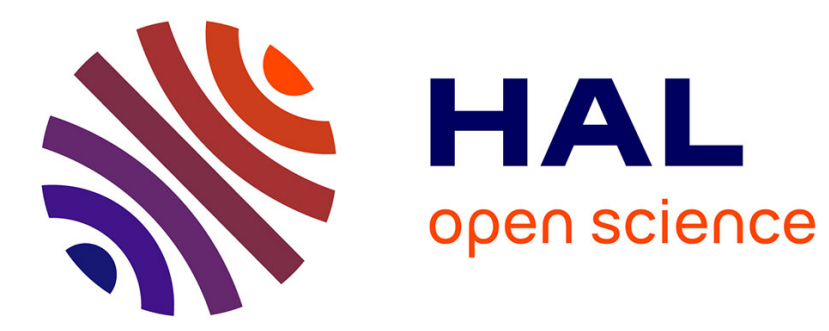

\title{
Aquatic hyphomycetes and litter decomposition in tropical - subtropical low order streams
}

\author{
Manuel A. S. Graça, Kevin Hyde, Eric Chauvet
}

\section{To cite this version:}

Manuel A. S. Graça, Kevin Hyde, Eric Chauvet. Aquatic hyphomycetes and litter decomposition in tropical - subtropical low order streams. Fungal Ecology, 2016, 19, pp.182-189. 10.1016/j.funeco.2015.08.001 . hal-01281924

\section{HAL Id: hal-01281924 \\ https://hal.science/hal-01281924}

Submitted on 9 Mar 2016

HAL is a multi-disciplinary open access archive for the deposit and dissemination of scientific research documents, whether they are published or not. The documents may come from teaching and research institutions in France or abroad, or from public or private research centers.
L'archive ouverte pluridisciplinaire HAL, est destinée au dépôt et à la diffusion de documents scientifiques de niveau recherche, publiés ou non, émanant des établissements d'enseignement et de recherche français ou étrangers, des laboratoires publics ou privés. 


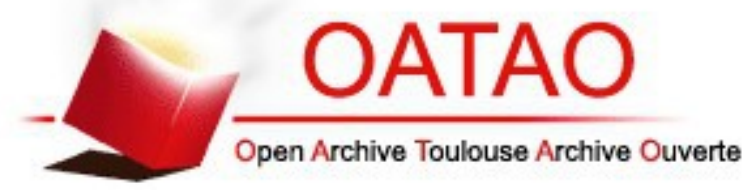

\section{Open Archive TOULOUSE Archive Ouverte (OATAO)}

OATAO is an open access repository that collects the work of Toulouse researchers and makes it freely available over the web where possible.

This is an author-deposited version published in : http://oatao.univ-toulouse.fr/ Eprints ID : 15522

To link to this article : DOI :10.1016/j.funeco.2015.08.001

URL : http://dx.doi.org/10.1016/j.funeco.2015.08.001

To cite this version : Graça, Manuel A. S. and Hyde, Kevin and Chauvet, Eric Aquatic hyphomycetes and litter decomposition in tropical - subtropical low order streams. (2016) Fungal Ecology, vol. 19. pp. 182-189. ISSN 1754-5048

Any correspondance concerning this service should be sent to the repository administrator: staff-oatao@,listes-diff.inp-toulouse.fr 


\title{
Aquatic hyphomycetes and litter decomposition in tropical - subtropical low order streams
}

\author{
Manuel A.S. GRAÇA ${ }^{a, *}$, Kevin HYDE $^{b, c}$, Eric CHAUVET ${ }^{d, e}$ \\ ${ }^{a}$ MARE - Marine and Environmental Sciences Centre, Department of Life Sciences, University of Coimbra, Portugal \\ binstitute of Excellence in Fungal Research, and School of Science, Mae Fah Luang University, Chiang Rai 57100, \\ Thailand \\ ${ }^{\mathrm{c}}$ Key Laboratory for Plant Diversity and Biogeography of East Asia, Kunming Institute of Botany, Chinese Academy of \\ Science, Kunming 650201, Yunnan, People's Republic of China \\ ${ }^{\mathrm{d}}$ Université de Toulouse, UPS, INP, EcoLab (Laboratoire Ecologie Fonctionnelle et Environnement), Toulouse, France \\ ${ }^{\mathrm{e}}$ EcoLab, CNRS, Toulouse, France
}

\begin{abstract}
A B S T R A C T
Leaf litter decomposition is an important ecosystem function carried out by a diverse array of consumers, including aquatic hyphomycetes. Aquatic hyphomycetes are found in streams worldwide, but their diversity and abundance varies across systems. In general, species diversity is lower across tropical and subtropical systems when compared with temperate biomes. The low diversity in tropical and subtropical areas may be related to: (a) lower seasonality; (b) our inability to detect fungi by traditional techniques; (c) low turbulence of rivers where many studies were carried out; (d) low nutrient content in many studied tropical systems; (e) leaves highly defended against consumers; and (f) competition from other decomposers. In terms of function, fungal biomass, sporulation rates and litter decomposition by aquatic hyphomycetes in the tropics was reported to be equivalent to or much lower than observed in temperate zones. The feeding ecology of shredder invertebrates is strongly related to the presence of microbial decomposers in the environment. The lack of shredders reported for some tropical rivers may be related to a low microbial biomass, well defended tropical leaves and frequent hydrological events which remove leaves before they can be used by shredders. Seasonal variations in rain fall in tropical and subtropical systems are likely to affect litter fall, the identity and quality of litter, the reproduction of aquatic hyphomycetes (due to turbulence effects) and therefore the community composition of aquatic hyphomycetes throughout the year. Future research on aquatic hyphomycetes and litter decomposition in the tropics and sub-tropics should address the diversity/identity gap, altitudinal gradient changes and the contribution of aquatic hyphomycetes to the trophic ecology of shredders.
\end{abstract}




\section{Introduction: aquatic hyphomycetes in the tropics and sub-tropics}

Aquatic systems are inhabited by a diverse array of decomposers which use dead plant tissues as an energy source. In this review we give an account of the aquatic hyphomycetes that grow on leaf litter, named "Ingoldian fungi" in honour of C.T. Ingold who discovered their typical substratum and habitat and described many new species (Shearer et al., 2006). These fungi have radiate and sigmoid asexually reproductive spores, adapted for life and dispersal in the flowing water. Their counterparts inhabiting lentic environments are aeroaquatic fungi, which are also hyphomycetes with typical spore morphology and life cycle. Aeroaquatic fungi will not be dealt with here. Other aquatic hyphomycetes also develop on woody litter. In studying aquatic litter fungi, the leaf litter and woody litter are generally examined in different ways and are treated as different fields. Yet there is an overlap in the fungi that decompose leaves and woody litter. The substrata are also studied in different ways -i.e. for woody litter, moist chambers are generally used (Tsui et al., 2000), while for leaf litter, studies use bubbles chambers (Chan et al., 2000a) or orbital shakers (Bärlocher, 2005). Thus different fungal assemblages are determined because of the methodology, but they overlap to a lesser or greater extent (Sridhar et al., 2010). In this paper we discuss only leaf litter inhabiting aquatic hyphomycetes, while the freshwater lignicolous fungi are reviewed in Hyde et al. (2016).

Earlier studies on aquatic hyphomycetes and their relationship with submerged leaves were those of Ingold (1942, 1943) in England with several new genera and species described. Soon aquatic hyphomycetes were studied in many other areas in Africa (Chergui and Pattee, 1991; Eicker and Baxter, 1999), the oceanic Islands (Ranzoni, 1979), Asia (Sridhar et al., 1992; Goh and Hyde, 1996; Goh, 1997; Chan et al., 2000a,b), Australia (Thomas et al., 1989), Caribbean islands (Marvanová and Marvan, 1969; Santos-Flores and BetancourtLópez, 1997), Europe (e.g. Marvanová and Müller-Haeckel, 1980), North America (e.g. Woelkerling and Baxter, 1968; Suberkropp and Klug, 1976), and South America (Nilsson, 1962; Schoenlein-Crusius and Grandi, 2003; 90 species referred).

Aquatic hyphomycetes have a worldwide distribution, with more than 300 estimated species, most of them recorded from temperate regions and fewer from the tropics and subtropics (Goh and Hyde, 1996; Shearer et al., 2006). In temperate systems, aquatic hyphomycetes are the most important fungal group of litter decomposers in streams and rivers (Suberkropp and Klug, 1974).

Due to their contrasting climatic and hydrological regimes, the tropics and sub-tropics encompass diverse environments ranging from dry desert zones, savannahs, and dry forests to swampy rain forests or peat swamps, and also covering a range of altitudes. Conditions in high-altitude tropical streams could be partially equivalent to those encountered in streams from temperate regions; we do not know if these similar conditions lead to convergence in species identity, diversity and function. The dynamics of litter input, litter decomposition and the environmental conditions imposed by the water chemistry and hydrology differ across the diverse tropical biomes, potentially controlling the diversity, ecology and function of aquatic hyphomycetes (e.g. Graça et al., 2015).

\section{Diversity}

One of the most conspicuous observations is that species diversity tends to increase towards the equator (Scheiner and Willig, 2007), but this tendency seems to be less pronounced in the case of many freshwater organisms (Hillebrand, 2004). It has been proposed that species richness of aquatic hyphomycetes peaks at mid latitudes (Shearer et al., 2006). Indeed, in the only study on litter decomposition and aquatic hyphomycete richness across a latitudinal gradient, Jabiol et al. (2013) found that species richness was distributed as predicted by Shearer et al. (2006), with low species richness in a tropical stream (rain forest). However, tropical ecosystems are very different from each other as stated above and should be treated separately. Aquatic hyphomycetes in decomposing litter have been reported in all tropical and sub-tropical systems, but their diversity and abundance varies across systems as we will show next.

Al-Riyami et al. (2009) reported that in permanent desert streams, the biomass of aquatic hyphomycetes colonizing decomposing leaves was similar to that reported in temperate regions, but the number of species was lower, perhaps as the diversity in the riparian vegetation was also low. The same was reported for North African streams (Chergui, 1990; Chergui and Pattee, 1991). Intermittent streams in dry areas (North Africa, Brazilian Caatinga and Australia) were also reported to have lower numbers of aquatic hyphomycete species and low fungal biomass (Boulton, 1991; Maamri et al., 2001, 1998; Silvada et al., 2014).

Tropical and subtropical grasslands occupy vast areas in Africa, Australia and South America. Studies of aquatic hyphomycetes in these areas are scarce, but the few studies have revealed few aquatic hyphomycetes species associated with decomposing leaves from the trees in the riparian zones (Schoenlein-Crusius, 2002; Sales et al., 2014). As with savannahs, in tropical seasonal semi-deciduous forest aquatic hyphomycetes on leaves were also less diverse than in temperate zones (Abelho et al., 2005; Smits et al., 2007; Ardón and Pringle, 2008; Rincón and Santelloco, 2009).

The high productivity of tropical rain forests (here also included the Brazilian "Atlantic Forest") is expected to result in large production of plant litter, a substratum for decomposers. Aquatic hyphomycetes have been reported from these systems (e.g. Schoenlein-Crusius et al., 1992) but, while Bärlocher et al. (2010) in Panama and Santos-Flores and Betancourt-Lopez (1997) in Puerto Rico reported a high number of species from submerged litter, other authors (e.g. Capps et al., 2011; Ferreira et al., 2012; Jabiol et al., 2013) found almost no conidia and/or very low fungal biomass from submerged litter.

Peat swamp forests are unique habitats found in the tropics. We are unaware of any studies targeting Ingoldian fungi in these habitats, but Pinnoi et al. (2006) and Pinruan et al. (2014) have studied the litter decomposing fungi in Sirindhorn peat swamp forest, Thailand, and Yule and Gomez 
(2009) looked at litter decomposition in Malaysian swamp forests. Litter decomposition was very slow in these systems and long-term accumulation of plant material under the acidic water-logged conditions mean peat swamps are one of the largest terrestrial organic sinks of carbon dioxide and thus extremely important. They are generally waterlogged and characterized by anaerobic soils and a thick layer of leaf litter, low nutrients and dissolved oxygen, dark coloured water due to tannins that leach from fallen leaves. Plant diversity is remarkably high and terrestrial fungal diversity is also high (Pinnoi et al., 2006; Pinruan et al., 2007, 2014). The diversity of fungi on submerged woody litter is, however, low (15 species 11 sexual and 4 asexual; Fryar et al., 2004) compared to that of other subtropical and tropical freshwater habitats (35-80, Ho et al., 2001, 2002; Cai et al., 2003). If the same tendency applies to all decomposers, then a low diversity of aquatic hyphomycetes would be expected.

From the above studies, it seems that aquatic hyphomycete diversity and abundance are generally low in tropical and sub-tropical systems. There are several potential reasons for their lower diversity:

(a) Seasonality. Shearer et al. (2006) proposed that the low seasonality of tropical and subtropical systems (in terms of temperature and litter input; but see below) results in lower environmental heterogeneity when compared with middle latitudes, which, in turn, results in low species diversity. The low seasonality of litter input leading to non-limiting resource to leaf decomposers has been reported from both lowland rivers and mountain streams (e.g. Mathuriau and Chauvet, 2002; Mathuriau et al., 2008).

(b) Different life histories resulting in low investment in reproduction by aquatic hyphomycetes. In this case, aquatic hyphomycetes would be there, but we are unable to notice their presence because the conidial production is low and traditionally aquatic hyphomycetes have been identified by the conidial morphology. Here the new molecular techniques, including denaturing gradient gel electrophoresis (DGGE) and terminal-restriction fragment length polymorphism (T-RFLP; e.g. Nikolcheva and Bärlocher, 2005; Seena et al., 2008) as well as next generation sequencing will soon be of help.

(c) Stream physical conditions. Some of the reports on litter decomposition and associated decomposers in tropical streams refer to work carried out in lowland streams or streams with low current and turbulence. Since conidial production by aquatic hyphomycetes is known to be stimulated by turbulence (e.g. Bärlocher et al., 2011) it is plausible that the low number of species reported could be the result of an unfavorable environment for sporulation.

(d) Low nutrient content in stream waters. Nutrients may limit fungal growth and enzymatic litter decomposition (e.g. Jabiol et al., 2013; Sales et al., 2014), and many tropical streams where the studies were carried out are oligotrophic.

(e) Low quality of substrata. It has been suggested that tropical tree species are better defended (chemically and physically; highly recalcitrant) against consumers than trees from other zones (Stout, 1989; Coley and Barone, 1996; Wantzen et al., 2002; Wright and Covich, 2005; but see Campbell and Fuchshuber, 1995; Ardón et al., 2009). Consistently, litter defense traits (e.g. leaf toughness) within the same litter functional types were found to be higher at low latitude (Jabiol et al. 2013; supplementary data). Many of such defenses could be effective protecting leaves after senescence. A hard leaf is a common defense caused by water and temperature stress in many tropical areas, including the rain forests (Julião et al., 2014). Highly defended leaves can act as an environmental filter, selecting for specialist taxa and retard microbial growth and reproduction.

(f) Competition from other decomposers. A large variety of aquatic fungi have been identified from submerged litter in the tropics (e.g. Wong et al., 1998; see below). It is plausible that in tropical systems these fungi may outcompete aquatic hyphomycetes in decomposing substrata. Bärlocher et al. (2012) reported that decomposing leaves of Eucalyptus viminalis in Australia released a large number of conidia, but the presence of zoosporic fungi was also registered. The capability of such fungi to decompose leaves has been poorly investigated.

\section{Function}

Except some pioneer works (e.g. Padgett, 1976), research on the function of aquatic hyphomycetes, i.e., their role in litter decomposition, in tropical streams has lagged behind counterpart studies on diversity and distribution. This likely results from the more recent concerns about stream ecosystem functioning in the tropics together with the need for facilities and specialized equipment for quantitative assessments, which may be complicated overseas in contrast with traditional prospecting and taxonomic collection.

In a pioneer cross latitudinal study, Irons et al. (1994) hypothesized microbial decomposition to be higher in tropical than in temperate streams, unlike invertebrate shredders, which exhibited the opposite pattern. Results from the literature supporting this hypothesis are still inconclusive. In their global study, Boyero et al. (2011) found a drastic decrease in invertebrates' involvement in leaf decomposition towards the tropics. At the same time, leaf decomposition by microorganisms (presumably mainly aquatic hyphomycetes) was the highest in the tropics and showed a positive relationship with temperature, as reflected by the constant across-latitude decomposition rate when expressed on a degree-day basis. Other studies support the greater microbial functional importance in the tropics, where stream shredders seem to be scarce when compared to temperate regions (Gonçalves et al., 2006; Handa et al., 2014). Mathuriau and Chauvet (2002) reported for two leaf species in a Colombian neotropical stream, peak biomass of $9 \%$ of detrital ash-free dry mass (AFDM) and 1 conidium produced per $\mu \mathrm{g}$ AFDM per day. These values were only slightly lower than those reported from temperate regions (Gessner, 1997). In a Venezuelan stream, Abelho et al. (2005) reported microbial biomass of up to $23 \%$ of detrital mass (based on ATP determinations), which even if not entirely constituted of mycelial biomass could suggest a 
prominent role of aquatic hyphomycetes in litter decomposition.

In contrast to the above reports, Ferreira et al. (2012) found a mycelial biomass and fungal reproductive activity 64 and 99 \%, respectively, lower in the Amazonian than in a Portuguese stream. Consistently, both lower mycelial biomass and rate of conidial production have been observed in tropical streams along latitudinal gradients examined by Handa et al. (2014) and Jabiol et al. (2013; A. Bruder and J. Jabiol, pers. com.). Interestingly, Gonçalves et al. (2007) pointed out that leaves decomposing in a Cerrado stream had lower mycelial biomass (as determined by ergosterol), but much higher ATP content (as an indicator of total microbial biomass) than leaves of the same plant species decomposing in a temperate stream (Portugal). Altogether this would mean that other microorganisms, presumably bacteria and/or protists, occur in high abundance on tropical leaves, but are perhaps only marginally involved in leaf decomposition.

The divergence among studies in terms of biomass and litter decomposition rates meditated by aquatic hyphomycetes may be partially due to the differences in methodologies used for detecting abundance and activities of these fungi. In addition, and probably more important, regional climatic variations can be responsible for between-study discrepancies, with tropical streams and rivers likely being much more variable than their temperate counterparts (Boyero et al., 2015).

\section{Interactions with invertebrates}

In temperate systems shredder invertebrates play a pivotal role in litter decomposition (Benfield and Webster, 1985; Graça, 2001). In the tropics and sub-tropics, the importance of shredders in litter decomposition seems to be less important than in temperate systems as judged by litter experiments excluding invertebrates (e.g. Boulton, 1991; Ardón and Pringle, 2008; Al-Riyami et al., 2009; Rincón and Santelloco, 2009; Boyero et al., 2011). Common shredders in temperate regions (e.g. trichoptera, amphipoda) are lacking in some tropical systems and their role as leaf consumers seems to be occupied by other invertebrates including scrapers (Boulton, 1991; Chergui and Pattee, 1991; Tanaka et al., 2006) or decapod omnivores (Crowl et al., 2006; Cogo and Santos, 2013; Tenkiano and Chauvet, 2015).

Feeding by shredders is strongly influenced by the presence of aquatic hyphomycetes in litter, which increases its nutrient $(\mathrm{N})$ content and makes it less tough and more assimilable (Bärlocher, 1992; Graça, 2001; Canhoto and Graça, 2008). Moreover, aquatic hyphomycetes can be directly consumed by shredders (reviewed by Canhoto and Graça, 2008) and increase shredder fitness, as measured by growth (Lawson et al., 1984) and reproductive output (Graça et al., 1993). Comparable information is uncommon for tropical areas. If aquatic hyphomycetes are less common in decomposing leaves in the tropics, what would be the role of aquatic hyphomycetes in the trophic ecology of litter consumers?

In places where aquatic hyphomycetes attain a large biomass in leaf litter, the lack or scarcity of shredders cannot be due to insufficient mycelial production and/or enzymatic maceration of leaf litter by aquatic fungi. An alternative explanation may lie in the quality of leaves, suspected to be lower in the tropics due to a higher content in chemical defense compounds (Stout, 1989; see also above), which may be more detrimental to invertebrate decomposers than to aquatic hyphomycetes. However, while some studies support this pattern (e.g. Dobson et al., 2002; Wantzen et al., 2002), others show similar concentrations of condensed tannins in tropical and temperate leaf litter (Campbell and Fuchshuber, 1995; Ardón et al., 2009).

Although litter production can be high as expected from high primary production in many tropical areas, less litter may be available for consumers in zones where frequent spates transport leaves to the banks, downstream areas or bury the leaves with inorganic sediments. Tropical fungi also grow more quickly than temperate species (Yuen et al., 1998), and therefore may degrade leaves more quickly which would be available to shredders for less time (see also Graça et al., 2015). Whether the relatively high importance of aquatic hyphomycetes in the tropics is related to the poor colonization of leaves by shredders, and the limited competition with other fungi, remains undetermined.

\section{Seasonality}

Contrary to conventional belief, tropical systems are, in some way, also seasonal in terms of litterfall, with different plants shedding leaves at different periods of the year (Sales et al., 2014), but generally with higher incidence in the dry season or at the beginning of the rainy season (Gonçalves et al., 2014). Moreover, green leaves enter the streams much more frequently in tropical systems than in the temperate regions; green leaves mechanically removed from trees by rain, wind or herbivores could be more nutritious to decomposers than senescent leaves (because reabsorption of nutrients has not occurred) and their decomposition could be carried out by a different array of decomposers. Furthermore, in temperate regions aquatic hyphomycete sporulation peaks in the autumn (Iqbal and Webster, 1973), which is the time of high rain and therefore higher turbulence. Consistently, in the Cerrado (South American Woody savannah), the peak of sporulation occurred during the rainy season (Sales et al., 2014). These observations on seasonal changes in litter input and turbulence may result in some seasonality in the abundance and dominance of aquatic hyphomycete conidia, and thus litter decomposition.

\section{Decay of woody litter by aquatic hyphomycetes}

Another group of aquatic fungi grow on woody litter (Wong et al., 1998) and these organisms decompose lignocelluloses, and are important in nutrient release from submerged wood (Yuen et al., 1998; Bucher et al., 2004). In contrast to the decreased diversity of freshwater leaf-inhabiting hyphomycetes, the freshwater lignicolous hyphomycete diversity is higher in tropical regions ranging from 25 species in a UK stream and 28 in a Japanese stream to $52-80$ species in tropical streams (Cai et al., 2003; Hu et al., 2010; Kurniawati et al., 
2010; Hyde et al., 2016). Unlike the leaf inhabiting aquatic fungi which predominantly produce asexual spores, the freshwater lignicolous fungi produce both asexual (aquatic hyphomycetes) and sexual morphs (aquatic ascomycetes) on submerged wood (or in moist chambers when wood is removed from streams) and should not be studied separately. The lignicolous freshwater fungi also occur on woody litter in lakes and ponds (Hyde and Goh, 1998; Luo et al., 2004; Sridhar et al., 2010), but the diversity is generally lower than in streams. The diversity, distribution and role of this group of fungi is reviewed by Hyde et al. (2016).

Investigation of fungi on woody litter using bubble chambers as well as moist chamber incubation is less common (Sridhar et al., 2010). The fungi revealed from bubble chamber incubation differed widely from those revealed in moist chamber incubation (Gönczöl and Révay, 1993; Sridhar et al., 2010). Aeration of bark and cambium from sites in the Western Ghats of India yielded 30 taxa of Ingoldian fungi, which is generally lower than that revealed from leaves. This is an under considered aspect of aquatic hyphomycete ecology.

\section{Conclusions and future works}

In this review we have discussed the aquatic hyphomycetes that grow on leaf litter in streams and condition the litter for consumption by shredders. The evidence suggests that the diversity of aquatic hyphomycetes is lower in tropical and subtropical areas than in temperate systems. Future research on aquatic hyphomycetes in the tropics should address some poorly investigated questions. To start with, is diversity really lower in the tropics than in temperate areas, or are we missing species because of the use of inadequate methodology? As pointed out above, new molecular biology techniques may soon address this question.

If aquatic hyphomycetes are really poorly represented in the tropics, what is the relative importance of aquatic hyphomycetes as compared with other fungi in tropical vs. temperate zones in litter decomposition?

Are altitudinal gradients in the tropics comparable to the latitudinal gradients? Since temperatures decrease by about $6.4^{\circ} \mathrm{C}$ for each $1000 \mathrm{~m}$ decrease in elevation, the question is whether high-altitude streams in the tropics resemble those in temperate regions in terms of litter decomposition and diversity and activity of aquatic hyphomycetes. This question is being investigated in the Ecuadorian Andes and Colorado Rocky mountains (Encalada et al., 2014) and in Borneo (Jinggut and Yule, 2015). As expected by the altitudinal - latitudinal equivalence, some montane Venezuelan tropical streams are rich in aquatic hyphomycetes (Cressa and Smits, 2007), and decomposition rates together with fungal biomass were high in Colombian montane streams where aquatic hyphomycetes were very important decomposers (Mathuriau and Chauvet, 2002).

Finally, what is the importance of aquatic hyphomycetes in the trophic ecology of shredders and other generalist detritivores? With some exceptions, the interactions between shredders and aquatic hyphomycetes have been poorly investigated. If shredders need litter conditioning by aquatic hyphomycetes or derive a large proportion of their energy or nutrient requirements from aquatic fungi, then aquatic hyphomycetes may be limiting the abundance of shredder invertebrates.

\section{Acknowledgements}

Manuel Graça acknowledges the IMAR and MARE for their research support. Kevin D. Hyde thanks the Chinese Academy of Sciences, project number 2013T2S0030, for the award of Visiting Professorship for Senior International Scientists at Kunming Institute of Botany.

\section{R E F E R E N C E S}

Abelho, M., Cressa, C., Graça, M.A.S., 2005. Microbial biomass, respiration, and decomposition of Hura crepitans $\mathrm{L}$. (Euphorbiaceae) leaves in a tropical stream. Biotropica 37, 397-402.

Al-Riyami, M., Victor, R., Seena, S., Elshafie, A.E., Bärlocher, F., 2009. Leaf decomposition in a mountain stream in the Sultanate of Oman. International Review of Hydrobiology 1, 16-28.

Ardón, M., Pringle, C.M., 2008. Do secondary compounds inhibit microbial- and insect-mediated leaf breakdown in a tropical rainforest stream, Costa Rica? Oecologia 155, 311-323.

Ardón, M., Pringle, C.M., Eggert, S.L., 2009. Does leaf chemistry differentially affect breakdown in tropical vs temperate streams? Importance of standardized analytical techniques to measure leaf chemistry. Journal of the North American Benthological Society 28, 440-453.

Bärlocher, F., 1992. The Ecology of Aquatic Hyphomycetes. Springer-Verlag, Berlin.

Bärlocher, F., 2005. Sporulation by aquatic hyphomycetes. In: Graça, M.A.S., Bärlocher, F., Gessner, M.O. (Eds.), Methods to Study Litter Decomposition: a Practical Guide. Springer, Dordrecht, pp. 185-188.

Bärlocher, F., Helson, J.E., Williams, D.D., 2010. Aquatic hyphomycete communities across a land-use gradient of Panamanian streams. Fundamental and Applied Limnology 177, 209-221.

Bärlocher, F., Stewart, M., Ryder, D.S., 2011. Analyzing aquatic fungal communities in Australia: impacts of sample incubation and geographic distance of streams. Czech Mycology 63, 113-132.

Bärlocher, F., Stewart, M., Ryder, D.S., 2012. Processing of Eucalyptus viminalis leaves in Australian streams - importance of aquatic hyphomycetes and zoosporic fungi. Fundamental and Applied Limnology 179, 305-319.

Benfield, E.F., Webster, J.R., 1985. Shredder abundance and leaf breakdown in an Appalachian Mountain stream. Freshwater Biology 15, 113-120.

Boulton, A.J., 1991. Eucalypt leaf decomposition in an intermittent stream in south-eastern Australia. Hydrobiologia 211, 123-136.

Boyero, L., Pearson, R.G., Gessner, M.O., Barmuta, L.A., Ferreira, V., Graça, M.A.S., Dudgeon, D., Boulton, A.J., Callisto, M., Chauvet, E., Helson, J.E., Bruder, A., Albariño, R.J., Yule, C.M., Arunachalam, M., Davies, J.N., Figueroa, R., Flecker, A.S., Ramírez, A., Death, R.G., Iwata, T., Mathooko, J.M., Mathuriau, C., Gonçalves, J.F., Moretti, M.S., Jinggut, T., Lamothe, S., M'Erimba, C., Ratnarajah, L., Schindler, M.H., Castela, J., Buria, L.M., Cornejo, A., Villanueva, V.D., West, D.C., 2011. A global experiment suggests climate warming will not accelerate litter 
decomposition in streams but might reduce carbon sequestration. Ecology Letters 14, 289-294.

Boyero, L., Pearson, R.G., Gessner, M.O., Dudgeon, D., Ramírez, A., Yule, C.M., Callisto, M., Pringle, C.M., Encalada, A.C., Arunachalam, M., Mathooko, J., Helson, J.E., Rincón, J., Bruder, A., Cornejo, A., Flecker, A.S., Mathuriau, C., MErimba, Gonçalves, J.F., Moretti, M., Jinggut, T., 2015. Leaf-litter breakdown in tropical streams: is variability the norm? Freshwater Science 34, 759-769.

Bucher, V.V.C., Hyde, K.D., Pointing, S.B., Reddy, C.A., 2004. Production of wood decay enzymes, mass loss and lignin solubilization in wood by diverse freshwater fungi. Microbial Ecology 48, 331-337.

Cai, L., Zhang, K.Q., McKenzie, E.H.C., Hyde, K.D., 2003. Freshwater fungi from bamboo and wood submerged in the Liput River in the Philippines. Fungal Diversity 13, 1-12.

Campbell, I.C., Fuchshuber, L., 1995. Polyphenols, condensed tannins, and processing rates of tropical and temperate leaves in an Australian stream. Journal of the North American Benthological Society 14, 174-182.

Canhoto, C., Graça, M.A.S., 2008. Interactions between fungi and stream invertebrates: back to the future. In: Sridhar, K.R., Bärlocher, F., Hyde, K.D. (Eds.), Novel Techniques and Ideas in Mycology. Hong Kong University Press, Honh Kong.

Capps, K.A., Graça, M.A.S., Encalada, A.C., Flecker, A.S., 2011. Leaf-litter decomposition across three flooding regimes in a seasonally flooded Amazonian watershed. Journal of Tropical Ecology 27, 205-210.

Chan, S.Y., Goh, T.K., Hyde, K.D., 2000a. Ingoldian fungi in Hong Kong. In: Hyde, K.D., Ho, W.H., Pointing, S.B. (Eds.), Aquatic Mycology across the Millenium, 5. Fungal Diversity, pp. 89-107

Chan, S.Y., Goh, T.K., Hyde, K.D., 2000b. Ingoldian fungi in Lam Tsuen River and Tai Po Kau Forest Stream, Hong Kong. In: Hyde, K.D., Ho, W.H., Pointing, S.B. (Eds.), Aquatic Mycology across the Millenium, 5. Fungal Diversity, pp. 109-118.

Chergui, H., 1990. The dynamics of aquatic hyphomycetes in an eastern Moroccan stream. Archiv furHydrobiololie 118, 341-352.

Chergui, H., Pattee, E., 1991. An experimental study of the breakdown of submerged leaves by hyphomycetes and invertebrates in Morocco. Freshwater Biology 26, 97-110.

Cogo, G.B., Santos, S., 2013. The role of aeglids in shredding organic matter in neotropical streams. Journal of Crustacean Biology 33, 519-526.

Coley, P.D., Barone, J.A., 1996. Herbivory and plant defenses in tropical forests. Annual Review of Ecology and Systematics 27, 305-335.

Cressa, C., Smits, G., 2007. Aquatic hyphomycetes in two blackwater streams of Venezuela. Ecotropicos 20, 82-85.

Crowl, T.A., Welsh, V., Heartsill-Scalley, T., Covich, A.P., 2006. Effects of different types of conditioning on rates of leaf-litter shredding by Xiphocaris elongata, a Neotropical freshwater shrimp. Journal of the North American Benthological Society 25, 198-208.

Dobson, M., Magana, A., Mathooko, J., Ndewga, F.K., 2002. Detritivores in Kenyan highland streams: more evidence for the paucity of shredders in the tropics? Freshwater Biology 47, 909-919.

Eicker, A., Baxter, A.P., 1999. An historical overview of Southern African systematic mycology. Transactions of the Royal Society of South Africa 54, 5-19.

Encalada, A.C., Salgado, C.A., Celinscak, C., Graça, M.A.S., Guayasamin, J., Flecker, A., Poff, L., 2014. Litter decomposition along altitudinal gradients in tropical and temperate streams. In: Joint Aquatic Sciences Meeting: Bridging Genes to Ecosystems: Aquatic Science at a Time of Rapid Change. May 18-21. Portland, Oregon. USA.
Ferreira, V., Encalada, A.C., Graça, M.A.S., 2012. Effects of litter diversity on decomposition and biological colonization of submerged litter in temperate and tropical streams. Freshwater Science 31, 945-962.

Fryar, S.C., Booth, W., Davies, J., Hodgkiss, I.J., Hyde, K.D., 2004. Distribution of fungi on wood in the Tutong River, Brunei. Fungal Diversity 17, 17-38.

Gessner, M.O., 1997. Fungal biomass, production and sporulation associated with particulate organic matter in streams. Limnetica 13, 33-44.

Goh, T.K., 1997. Tropical freshwater hyphomycetes. In: Hyde, K.D. (Ed.), Biodiversity of Tropical Microfungi. Hong Kong University Press, Hong Kong, pp. 189-227.

Goh, T.K., Hyde, K.D., 1996. Biodiversity of freshwater fungi. Journal of Industrial Microbiology 17, 328-345.

Gonçalves, J.F., Graca, M.A.S., Callisto, M., 2006. Leaf-litter breakdown in 3 streams in temperate, Mediterranean, and tropical Cerrado climates. Journal of the North American Benthological Society 25, 344-355.

Gonçalves, J.F., Graça, M.A.S., Callisto, M., 2007. Litter decomposition in a Cerrado savannah stream is retarded by leaf toughness, low dissolved nutrients and a low density of shredders. Freshwater Biology 52, 1440-1451.

Gonçalves, J.F., Rezende, R.S., Gregório, R.S., Valentin, G.C., 2014. Relationship between dynamics of litterfall and riparian plant species in a tropical stream. Limnologica 44, 40-48.

Gönczöl, J., Révay, A., 1993. Further studies on fungal colonization of twigs in the Morgo-stream, Hungary. Nova Hedwigia 56, 531-542.

Graça, M.A.S., 2001. The role of invertebrates on leaf litter decomposition in streams - a review. International Review of Hydrobiology 86, 383-393.

Graça, M.A.S., Ferreira, V., Canhoto, C., Encalada, A.C., GuerreroBolaño, F., Wantzen, K.M., Boyero, L., 2015. A conceptual model of litter breakdown in low order streams. International Review of Hydrobiology 100, 1-12.

Graça, M.A., Maltby, L., Calow, P., 1993. Importance of fungi in diet of Gammarus pulex and Asellus aquaticus. II. Effects on growth, reproduction and physiology. Oecologia 96, 304-309.

Handa, I.T., Aerts, R., Berendse, F., Berg, M.P., Bruder, A., Butenschoen, O., Chauvet, E., Gessner, M.O., Jabiol, J., Makkonen, M., McKie, B.G., Malmqvist, B., Peeters, E.T.H.M., Scheu, S., Schmid, B., van Ruijven, J., Vos, V.C.A., Hättenschwiler, S., 2014. Consequences of biodiversity loss for litter decomposition across biomes. Nature 509, 218-221.

Hillebrand, H., 2004. On the generality of the latitudinal diversity gradient. American Naturalist 163, 192-211.

Ho, W.H., Hyde, K.D., Hodgkiss, I.J., Yanna, 2001. Fungal communities on submerged wood from streams in Brunei, Hong Kong and Malaysia. Mycological Research 105, 1492-1501.

Ho, W.H., Yanna, Hyde, K.D., Hodgkiss, I.J., 2002. Seasonality and sequential occurrence of fungi on wood submerged in Tai Po Kau Forest Stream, Hong Kong. Fungal Diversity 10, 21-43.

Hu, D.M., Cai, L., Chen, H., Bahkali, A.H., Hyde, K.D., 2010. Fungal diversity on submerged wood in a tropical stream and an artificial lake. Biodiversity and Conservation 19, 3799-3808.

Hyde, K.D., Goh, T.K., 1998. Fungi on submerged wood in Lake Barrine, north Queensland, Australia. Mycological Research 102, 739-749.

Hyde, K.D., Fryar, S., Tian, Q., Bahkali, A.H., Xu, J.C., 2016. Lignicolous freshwater fungi along a north-south latitudinal gradient in the Asian/Australian region; can we predict the impact of global warming on biodiversity and function? Fungal Ecol. 19, 190-200. 
Ingold, C.T., 1942. Aquatic hyphomycetes of decaying alder leaves. Transactions of the British Mycological Society 25, 339-417.

Ingold, C.T., 1943. On the distribution of aquatic hyphomycete saprophytic on submerged decaying leaves. New Phytologist 42, 139-143.

Irons, J.G., Oswood, M.W., Stout, R.J., Pringle, C.M., 1994. Latitudinal patterns in leaf litter breakdown: is temperature really important? Freshwater Biology 32, 401-411.

Iqbal, S.H., Webster, J., 1973. Aquatic hyphomycete spora of the River Exe and its tributaries. Transactions of the British Mycological Society 61, 331-346.

Jabiol, J., Bruder, A., Gessner, M.O., Makkonen, M., McKie, B.G., Peeters, E.T.H.M., Vos, V.C.A., Chauvet, E., 2013. Diversity patterns of leaf-associated aquatic hyphomycetes along a broad latitudinal gradient. Fungal Ecology 6, 439-448.

Jinggut, T., Yule, C.M., 2015. Leaf litter breakdown in streams of East Malaysia (Borneo) along an altitudinal gradient: initial nitrogen content of litter limits shredder feeding. Freshwater Science 34, 691-701.

Julião, G.R., Venticinque, E.M., Fernandes, G.W., Price, P.W., 2014. Unexpected high diversity of galling insects in the Amazonian Upper Canopy: the Savanna out there. PLoS One. http:// dx.doi.org/10.1371/journal.pone.0114986.

Kurniawati, E., Zhang, H., Chukeatirote, E., Sulistiowati, L., Moslem, M.A., Hyde, K.D., 2010. Diversity of freshwater ascomycetes in freshwater bodies at Amphoe Mae Chan, Chiang Rai. Cryptogamie Mycologie 31 (3), 323-331.

Lawson, D., Klug, M., Merritt, R., 1984. The influence of physical, chemical and microbiological characteristics of decomposing leaves on the growth of the detritivore Tipula abdominalis. Canadian Journal of Zoology 62, 2339-2343.

Luo, J., Yin, J.F., Cai, L., Zhang, K.Q., Hyde, K.D., 2004. Freshwater fungi in Lake Dianchi, a heavily polluted lake in Yunnan, China. Fungal Diversity 16, 93-112.

Maamri, A., Bärlocher, F., Pattee, E., Chergui, H., 2001. Fungal and bacterial colonisation of Salix pedicellata leaves decaying in permanent and intermittent streams in Eastern Morocco. International Review of Hydrobiology 86, 337-348.

Maamri, A., Chauvet, E., Chergui, H., Gourbiere, F., Pattee, E., 1998. Microbial dynamics on decaying leaves in a temporary Moroccan river. I - Fungi. Archiv fur Hydrobiologie 144, 41-59.

Marvanová, L., Marvan, P., 1969. Aquatic hyphomycetes in Cuba. Ceska Mykologie 23, 135-139.

Marvanová, L., Müller-Haeckel, A., 1980. Water-borne spores in foam in a subarctic stream system in Sweden. Sydowia 33, 210-220.

Mathuriau, C., Chauvet, E., 2002. Breakdown of leaf litter in a neotropical stream. Journal of the North American Benthological Society 21, 384-396.

Mathuriau, C., Thomas, A.G.B., Chauvet, E., 2008. Seasonal dynamics of benthic detritus and associated macroinvertebrate communities in a neotropical stream. Fundamental and Applied Limnology/Archiv Für Hydrobiologie 171, 323-333.

Nikolcheva, L.G., Bärlocher, F., 2005. Seasonal and substrate preferences of fungi colonizing leaves in streams: traditional versus molecular evidence. Environmental Microbiology 7, 270-280.

Nilsson, S., 1962. Some aquatic hyphomycetes from South America. Suensk Botanisk Tidskrift 56, 351-361.

Padgett, D.E., 1976. Leaf decomposition by fungi in tropical rainforest streams. Biotropica 8, 166-178.

Pinnoi, A., Lumyong, S., Hyde, K.D., Jones, E.B.G., 2006. Biodiversity of fungi on the palm Eleiodoxa conferta in Sirindhorn peat swamp forest, Narathiwat, Thailand. Fungal Diversity 22, 205-208.
Pinruan, A., Pinnoi, A., Hyde, K.D., Jones, E.B.G., 2014. Tropical peat swamp fungi with special reference to palms. In: Jones, E.B.G., Hyde, K.D., Pang, K.L. (Eds.), Freshwater Fungi, pp. 371-386.

Pinruan, U., Lumyong, S., Hyde, K.D., Jones, E.B.G., 2007. Occurrence of fungi on tissues of the peat swamp palm Licuala longicalycata. Fungal Diversity 25, 157-173.

Ranzoni, F.V., 1979. Aquatic hyphomycetes from Hawaii. Mycologia 71, 786-795.

Rincón, J., Santelloco, R., 2009. Aquatic fungi associated with decomposing Ficus sp. leaf litter in a neotropical stream. Journal of the North American Benthological Society 28, 416-425.

Sales, M.A., Gonçalves, J.F., Dahora, J.S., Medeiros, A.O., 2014. Influence of leaf quality in microbial decomposition in a headwater stream in the Brazilian Cerrado: a 1-year study. Microbial Ecology 69, 84-94.

Santos-Flores, C.J., Betancourt-López, C., 1997. Aquatic and Water-borne Hyphomycetes (Deuteromycotina): in Streams of Puerto Rico, Including Records from Other Neotropical Locations (No. 2). College of Arts and Sciences, University of Puerto Rico.

Scheiner, S.M., Willig, M.R., 2007. A general theory of ecology. Theoretical Ecology 1, 21-28.

Schoenlein-Crusius, I.H., 2002. Aquatic hyphomycetes from cerrado regions in the state of Sao Paulo, Brazil. Mycotaxon 81, 457-462.

Schoenlein-Crusius, I.H., Grandi, R.A.P., 2003. The diversity of aquatic hyphomycetes in South America. Brazilian Journal of Microbiology 34, 183-193.

Schoenlein-Crusius, I.H., Pireszottarelli, C.L.A., Milanez, A.I., 1992. Aquatic fungi in leaves submerged in a stream in the Atlantic rain-forest. Revista de Microbiologia 23, 167-171.

Seena, S., Wynberg, N., Bärlocher, F., 2008. Fungal diversity during leaf decomposition in a stream assessed through clone libraries. Fungal Diversity 30, 1-14.

Shearer, C.A., Descals, E., Kohlmeyer, B., Kohlmeyer, J., Marvanová, L., Padgett, D., Porter, D., Raja, H.A., Schmit, J.P., Thorton, H.A., Voglymayr, H., 2006. Fungal biodiversity in aquatic habitats. Biodiversity and Conservation 16, 49-67.

Silva, S.S.da, Izabel, T.S.S., Gusmão, F.P., 2014. Fungos conidiais associados a substratos vegetais submersos em algumas áreas do bioma da Caating. Rodriguésia 65, 527-538.

Smits, G., Fernandez, R., Cressa, C., 2007. Preliminary study of aquatic hyphomycetes from Venezuelan streams. Acta Botanica Venezuelica 30, 345-355.

Sridhar, K.R., Chandraskar, K.R., Kaveriappa, K.M., 1992. Research on the Indian subcontinent. In: Billings, W.D., Golley, F., Lange, O.L., Olson, J.S., Remmert, H. (Eds.), The Ecology of Aquatic Hyphomycetes, vol. 94, pp. 182-211.

Sridhar, K.R., Karamchand, K.S., Hyde, K.D., 2010. Wood-inhabiting filamentous fungi in 12 high-altitude streams of the Western Ghats by damp incubation and bubble chamber incubation. Mycoscience 51, 104-115.

Stout, J., 1989. Effects of condensed tannins on leaf processing in mid-latitude and tropical streams: a theoretical approach. Canadian Journal of Fisheries and Aquatic Sciences 46, 1097-1106.

Suberkropp, K., Klug, M.J., 1974. Decomposition of deciduous leaf litter in a woodland stream I. A scanning electron microscopic study. Microbial Ecology 1, 96-103.

Suberkropp, K., Klug, M.J., 1976. Fungi and bacteria associated with leaves during processing in a woodland stream. Ecology 57, 707-719.

Tanaka, M.O., Ribas, A.C.A., de Sousa, A.L.T., 2006. Macroinvertebrate succession during leaf litter breakdown in a perennial karstic river in Western Brasil. Hydrobiologia 568, 493-498. 
Tenkiano, N., Chauvet, E., 2015. Leaf litter breakdown in Guinean streams: insight into the relative contribution of decomposers in the tropics. In: SEFS9: 9th Symposium for European Fresh Water Sciences, Geneva, pp. 5-10.

Thomas, K., Chilvers, G.A., Norris, R.H., 1989. Seasonal occurrence of conidia of aquatic hyphomycetes (fungi) in Lees Creek, Australian Capital Territory. Australian Journal of Marine and Freshwater Research 40, 11-24.

Tsui, C.K.M., Hyde, K.D., Hodgkiss, I.J., 2000. Biodiversity of fungi on submerged wood in Hong Kong streams. Aquatic Microbial Ecology 21, 289-298.

Wantzen, K.M., Wagner, R., Junk, W.J., 2002. How do plantherbivore interactions of trees influence coarse detritus processing by shredders in aquatic ecosystems of different latitudes? Verhandlungen. Internationale Vereinigung fuer theoretische und angewandte Limnologie 28, 815-821.
Woelkerling, W., Baxter, J., 1968. Aquatic hyphomycetes of Wisconsin: distribution and ecology. Mycopathologia et Mycologia Applicata 35, 33-36.

Wong, M.K.M., Goh, T.K., Hodkiss, I.J., Hyde, K.D., Ranghoo, V.M., Tsui, C.K.M., Ho, W.H., 1998. Role of fungi in freshwater ecosystems. Biodiversity and Conservation 7, 1187-1206.

Wright, M.S., Covich, A.P., 2005. The effect of macroinvertebrate exclusion on leaf breakdown rates in a tropical headwater stream. Biotropica 37, 403-408.

Yuen, T.K., Hyde, K.D., Hodgkiss, I.J., 1998. Physiological growth parameters and enzyme production in tropical freshwater fungi. Material und Organismen 32, 2-16.

Yule, C.M., Gomez, L.N., 2009. Leaf litter decomposition in a tropical peat swamp forest in Peninsular Malaysia. Wetlands Ecology and Management 17, 231-241. 